Article

\title{
Immobilization of Planococcus sp. S5 Strain on the Loofah Sponge and Its Application in Naproxen Removal
}

\author{
Anna Dzionek ${ }^{1}$, Danuta Wojcieszyńska ${ }^{1}$, Katarzyna Hupert-Kocurek ${ }^{1}$, \\ Małgorzata Adamczyk-Habrajska ${ }^{2}$ and Urszula Guzik 1,* (D) \\ 1 Department of Biochemistry, Faculty of Biology and Environmental Protection, University of Silesia in \\ Katowice, Jagiellońska 28, 40-032 Katowice, Poland; adzionek@us.edu.pl (A.D.); \\ danuta.wojcieszynska@us.edu.pl (D.W.); katarzyna.hupert-kocurek@us.edu.pl (K.H.-K.) \\ 2 Institute of Technology and Mechatronics, University of Silesia in Katowice, Żytnia 12, 41-200 Sosnowiec, \\ Poland; malgorzata.adamczyk-habrajska@us.edu.pl \\ * Correspondence: urszula.guzik@us.edu.pl; Tel.: +32-200-9567
}

Received: 30 March 2018; Accepted: 23 April 2018; Published: 26 April 2018

\begin{abstract}
Planococcus sp. S5, a Gram-positive bacterium isolated from the activated sludge is known to degrade naproxen in the presence of an additional carbon source. Due to the possible toxicity of naproxen and intermediates of its degradation, the whole cells of S5 strain were immobilized onto loofah sponge. The immobilized cells degraded 6, 9, 12 or $15 \mathrm{mg} / \mathrm{L}$ of naproxen faster than the free cells. Planococcus sp. cells immobilized onto the loofah sponge were able to degrade naproxen efficiently for 55 days without significant damage and disintegration of the carrier. Analysis of the activity of enzymes involved in naproxen degradation showed that stabilization of S5 cells in exopolysaccharide (EPS) resulted in a significant increase of their activity. Changes in the structure of biofilm formed on the loofah sponge cubes during degradation of naproxen were observed. Developed biocatalyst system showed high resistance to naproxen and its intermediates and degraded higher concentrations of the drug in comparison to the free cells.
\end{abstract}

Keywords: whole-cell immobilization; loofah sponge; Planococcus sp. S5; naproxen

\section{Introduction}

In recent years more attention has been paid to the presence of various medicines in the natural environment. One of them is naproxen (2-(6-methoxy-2-naphthyl)propionic acid) which belongs to the group of polycyclic Non-Steroidal Anti-Inflammatory Drugs (NSAIDs). This drug is not metabolized in human body and the sewage treatment plants are not adapted to its utilization. Therefore, naproxen has been releasing into the natural environment in an unchanged form for over 40 years. Due to its continuous accumulation in the environment, naproxen is now one of the most frequently detected drug in surface and drinking water (concentration in the range 0.01-2.6 $\mu \mathrm{g} / \mathrm{L}$ ) [1-3].

The most efficient methods for naproxen removal from the environment are based on the physicochemical processes. However, the biggest disadvantage of these methods is generation of products with greater toxicity than the drug itself and formation of free radicals that directly damage biological structures [3-6]. The use of microorganisms in naproxen utilization brings many benefits. Bioremediation is based on the capabilities of selected microorganisms for accumulation, transformation, detoxification or degradation of pollutants. This technology is environmentally friendly, cheap and effective [7-9].

During application of microbial cells in bioremediation processes, extremely important is their immobilization. It allows increasing microbial degradation capacity, extends viability and catalytic 
activity of cells introduced into bioremediation systems as well as increases the chances of microbial cells survival and adaptation to changing environment. In immobilization process, microbial cells are trapped in polymeric gels (entrapment, encapsulation) or on the surface of various carriers (adsorption, electrostatic or covalent binding on the surface). However, the main disadvantages of immobilization are: limitation of diffusion, leakage of cells into the medium or lowering their catalytic functions depending on the binding compounds used. Recently, immobilization based on the natural ability of some microorganisms to biofilm formation on the surface of various carriers is gaining more attention. Through the existence of many microenvironments in the biofilm, cells are less vulnerable to changing environmental conditions. Created in this way stable matrix is also characterized by a high degree of heterogeneity in which microbial cells are protected against anti-bacterial agents and bacteriophages and are able to degrade contaminants at higher concentrations $[8,10,11]$.

From an economic point of view, the carrier and the procedure for immobilization of microorganisms should be cheap. Therefore, natural and organic carriers are widely used in bioremediation processes $[8,12]$. These biodegradable and biocompatible supports are characterized by hydrophilic surface on which many functional groups are located. Among these natural carriers, particular attention is paid to the group of lignocellulolistic plant materials. One of them is loofah sponge derived from the dry mature fruit of Luffa aegyptiaca, grown in most subtropical and tropical regions. This sponge is composed of an open network of fibres that form the skeleton of the fruit. The main advantages of this material are its high porosity, low price, non-toxicity, simple application and operation technique and high mechanical resistance [13-15].

The present work is a continuation of studies on bacterial degradation of NSAIDs. Our previous study showed the ability of Gram-positive Planococcus sp. S5 to catalyse naproxen degradation under cometabolic conditions [2]. The aim of this study was to investigate the effect of immobilization of Planococcus sp. S5 cells on the loofah sponge on degradation processes. The degradation capacity of the developed biocatalyst at various concentrations of naproxen and its reusability were examined. To investigate how immobilization affected degradation activity of S5 strain, the activity of enzymes involved in naproxen utilization was examined. Additionally, visualization of biofilm formed on the surface of the carrier and its changes during drug degradation was performed. This is the first report about degradation of naproxen by immobilized bacterial cells. Moreover, the results of these studies enable evaluation of potential application of tested strain in bioremediation systems.

\section{Results and Discussion}

\subsection{Immobilization of Planococcus sp. S5 on Loofah Sponge}

The natural ability of some microorganisms to colonize surface of porous materials is a key feature for efficient immobilization. At the beginning, process of cells attachment to the surface is reversible and cells may be easily removed from the carrier by washing. In the second phase, cells which synthesize extracellular polymeric substances bind to the surface of the carrier with such a force that more invasive process is needed to remove them. Taking into consideration stability of the constructed biocatalyst, it is desirable that the formed biofilm should be strongly bound to the carrier. This feature depends on the species of the microorganism and the type of the surface. Additionally, selection of proper conditions of immobilization can improve the quality of biofilm [16-18]. To verify the quality of biofilm formed by S5 strain, which corresponds to its catalytic functions, its physiological state was evaluated by determination of its ability to hydrolyse fluorescein diacetate by non-specific esterases produced by alive bacterial cells (total enzymatic activity). This assay was chosen due to its simplicity, short incubation time $(1 \mathrm{~h})$ and possibility of spectrophotometric determination of the data. What is more important, the test used is correlated with other bacterial indicators such as an amount of biomass or adenosine triphosphate (ATP) and the oxygen consumption [19,20].

Selection of the optimal conditions for immobilization of the whole bacterial cells by their adsorption on the surface is an extremely important in designing of biocatalyst systems. Due to 
the diversity of bacteria, optimization should be carried out for each immobilized strain. Strain Planococcus sp. S5, which was isolated from the activated sludge from a sewage treatment plant in Bytom Miechowice (Poland), was able to degrade aromatic compounds like salicylate, benzoate, hydroxybenzoate and dihydroxybenzoate and phenol [21,22]. However, this is the first report regarding its immobilization and one of a few on the ability of biofilm formation by bacteria from Planococcus genus [23].

Procedure of Planococcus sp. S5 immobilization on the loofah sponge through its adsorption on the surface was developed by optimizing each parameter to obtain the highest amount and enzymatic activity of immobilized microorganisms. Immobilization of S5 cells on the loofah sponge was the most effective in mineral salts medium ( $\mathrm{pH} 7.2)$, in the presence of glucose and manganese salt, during bacteria incubation with shaking $(90 \mathrm{rpm})$ at $30^{\circ} \mathrm{C}$. The effect of the growth phase on immobilization process was also observed. The best results were obtained for a culture at stationary phase. Immobilization of S5 strain was also more efficient during the osmotic stress caused by a higher concentration of $\mathrm{NaCl}(19 \mathrm{~g} / \mathrm{L})$ and at high number of cells in the medium (initial $\mathrm{OD}_{600}$ equal to 1.2) (Figure S1).

It has been proven that limitation of carbon source in the medium stimulates biofilm formation by Bacillus subtilis by activating the Spo0A transcription factor [24]. This mechanism enables survival and proliferation of bacteria during nutrient deficiency at which growth in the form of planktonic cells is impossible. On the other hand, Staphylococcus aureus and Staphylococcus epidermidis form biofilms only when glucose is present in the medium because it is necessary for the synthesis of adhesins [25]. Therefore, since S5 strain is not spores producing bacterium [21], efficient immobilization in the presence of glucose probably resulted from synthesis of adhesins which are involved in attachment of cells to the carrier. Bacteria of genus Planococcus are known to be moderately halophilic [26-28]. Recent research [23] shows that osmotic stress favours the formation of biofilm by Planococcus rifietoensis by increasing production of exopolysaccharides (EPS), which additionally improves water holding capacity at higher salt concentrations.

The developed method of S5 strain immobilization on the loofah sponge resulted in $0.0191 \pm 0.0022 \mathrm{~g}$ of Planococcus sp. S5 cells (dry mass) immobilized on each loofah cube, able to hydrolysis of $23.88 \pm 1.06 \mu \mathrm{g}$ of fluorescein diacetate during $1 \mathrm{~h}$ (total enzymatic activity) (Figure 1). Results for fluorescein diacetate hydrolysis and fluorescein adsorption by unimmobilized loofah cubes were not statistically significant.

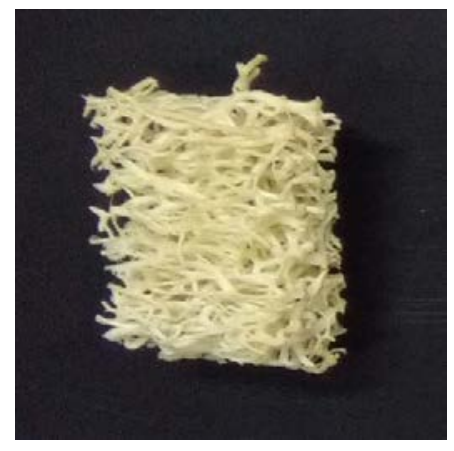

(a)

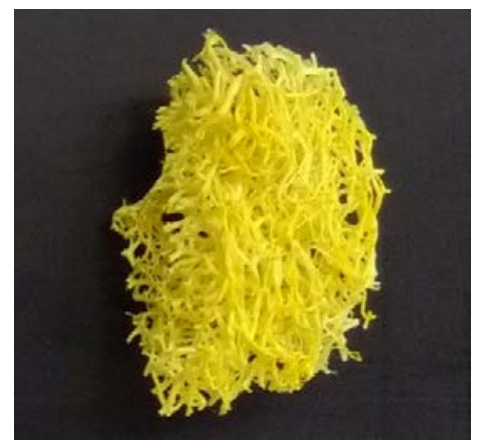

(b)

Figure 1. Loofah sponges cubes after total enzymatic activity assay; (a) unimmobilized carrier (b) loofah cubes after incubation with Planococcus sp. S5 cells. 


\subsection{Naproxen Biodegradation}

\subsubsection{Biodegradation of Different Concentration of Naproxen}

Naproxen (2-(6-methoxy-2-naphthyl)propionic acid)) belongs to the propionic acid derivatives family. Due to the presence of two aromatic rings, naproxen biodegradation is more difficult than monocyclic NSAIDs. Only a few strains (mainly white-rot fungi) are known to possess enzymatic systems which enable them to acquire carbon and energy from naproxen [29,30]. Biodegradation of naproxen by bacterial strains is a process that is being explored. However, none of the known bacterial strains-Planococcus sp. S5 [2], Bacillus thuringiensis B1(2015b) [31], Stenotrophomonas maltophilia KB2 [32], Pseudomonas sp. CE21 [33] - are able to use naproxen as the sole carbon source. First study about naproxen biodegradation by strain Planococcus sp. S5 [2] revealed that the addition of glucose which was readily available source of carbon and energy resulted with complete biodegradation of the drug. However, due to the negative effect of naproxen on the total enzymatic activity of free S5 cells, the degradation of the drug at a concentration of $6 \mathrm{mg} / \mathrm{L}$ lasted 38 days (data not published). For this reason it was decided to carry out the immobilization process.

Loofah sponge due to the relatively large surface area and chemical composition (cellulose, hemicellulose, lignin) shows good sorption properties. However, making the loofah sponge capable of sorption of hydrophobic substances (like naproxen) requires subjecting it to a cooking process with $\mathrm{NaOH}$ to increase its hydrophobicity and to create available vacant sites [34,35]. For this reason, the loofah sponge in this study has not been subjected to a cooking process with $\mathrm{NaOH}$ to limit its sorption capacity. Another important factor that needed to be consider in biodegradation studies with immobilized cells by adsorption of the surface is accumulation of xenobiotics in biofilm. This phenomenon is related to the sorption properties of exopolysaccharides (EPS). While the sorption of positively-charged compounds by EPS is more efficient due to anionic nature of biofilm, sorption of anionic organic molecules is limited due to electrostatic repulsion [36].

There was no changes observed in drug concentration during incubation with sterile non-immobilized carriers, which confirms lack of the naproxen adsorption capacities by prepared in that way loofah sponges. Naproxen was also not detected in the biofilm formed onto the loofah sponges by Planococcus sp. S5. Obtained results demonstrated that loss of the drug from the medium during biodegradation experiments was caused only by immobilized cells of Planococcus sp. S5.

To investigate whether the immobilization onto the loofah sponges affected the degradation capacity of Planococcus sp. S5, biodegradation of various concentrations of naproxen $(6,9,12$ or $15 \mathrm{mg} / \mathrm{L}$ ) by immobilized cells with respect to non-immobilized cells was tested (Figures 2 and 3).

Observation of the efficiency of the naproxen cometabolic biodegradation conducted by free cells of Planococcus sp. S5 showed that they were able to degrade naproxen in concentration 6, 9 and $12 \mathrm{mg} / \mathrm{L}$ respectively in 38, 44 and 62 days. Biodegradation of the highest tested concentration of the drug $(15 \mathrm{mg} / \mathrm{L})$ stopped after biodegradation of $29 \%$ of naproxen (Figure 2a). Obtained results shows that the free cells of S5 strain were able to complete cometabolic naproxen biodegradation at a concentration up to $12 \mathrm{mg} / \mathrm{L}$. Higher drug concentrations showed inhibitory effects on free cells of the S5 strain. Immobilization of Planococcus sp. S5 cells onto the loofah sponges resulted in a significant acceleration of the naproxen cometabolic biodegradation. It was observed a complete biodegradation of 6, 9, 12 and $15 \mathrm{mg} / \mathrm{L}$ of naproxen respectively after 17, 32, 43 and 53 days (Figure 2b). 


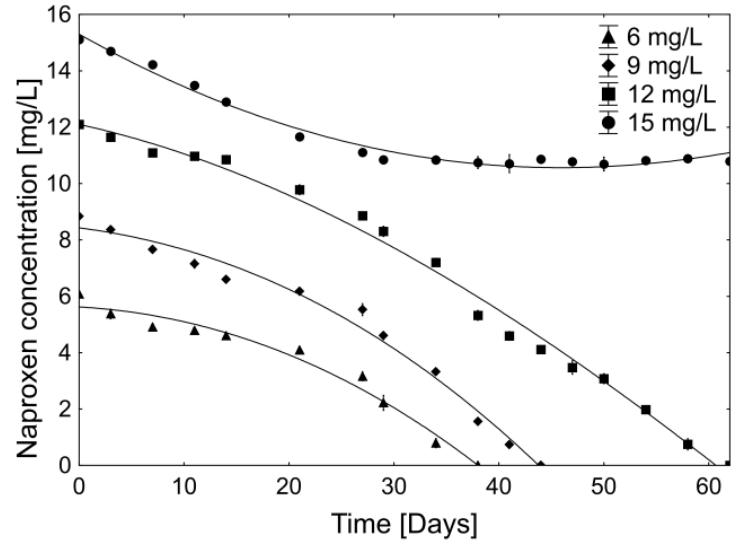

(a)

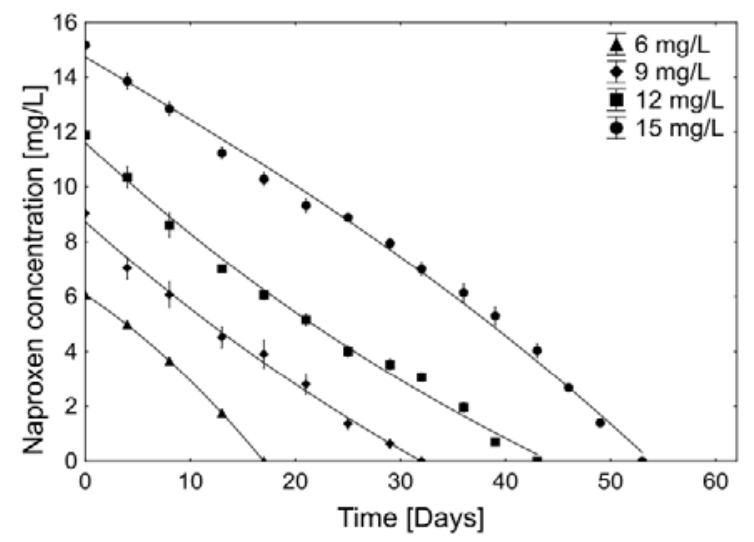

(b)

Figure 2. Cometabolic degradation of 6, 9, 12 and $15 \mathrm{mg} / \mathrm{L}$ naproxen by (a) free cells of Planococcus sp. S5; (b) cells of Planococcus sp. S5 immobilized onto the loofah sponge. Data presented as mean \pm standard deviation of three replicates.

In order to evaluate changes in the course of the biodegradation process, the rate of naproxen biodegradation was calculated (Tables 1 and 2). Biodegradation rates by free cells of S5 were statistically different (Test $T, p \geq 0.05$ ) than by immobilized cells. During the biodegradation of naproxen by free cells, in the initial phase the slower drug degradation was observed, independently of the drug concentration (average $6.3 \pm 3.4 \mu \mathrm{g} / \mathrm{h}$ ). After 29 days twice faster biodegradation of the drug $(12.0 \pm 4.5 \mu \mathrm{g} / \mathrm{h})$ was observed that lasted until the end of biodegradation (Table 1). Designation of the naproxen biodegradation rates by immobilized cells of $\mathrm{S} 5$ strain revealed its almost linear and constant course $(12.1 \pm 4 \mu \mathrm{g} / \mathrm{h})$ (Table 2). Interestingly, there was no significant difference between naproxen biodegradation rates by the immobilized cells and by free cells during faster drug degradation phase (Test $\mathrm{T}, p \geq 0.05$ ). This situation was most likely caused by the fact that cells in the biofilm exhibit characteristics of the stationary phase (altered genetic expression profile and slower growth) [37]. Confirmation of this hypothesis is the fact that the phase of faster naproxen degradation by free cells of Planococcus sp. S5 occurred when cells entry into the stationary phase (data not published).

Table 1. Naproxen degradation rates by free cells of Planococcus sp. S5. Data presented as a mean \pm standard deviation of three replicates.

\begin{tabular}{|c|c|c|c|c|}
\hline \multirow{2}{*}{ Period [Day-Day] } & \multicolumn{4}{|c|}{ Average Naproxen Degradation Rate $[\mu \mathrm{g} / \mathrm{h}]$} \\
\hline & $6 \mathrm{mg} / \mathrm{L}$ & $9 \mathrm{mg} / \mathrm{L}$ & $12 \mathrm{mg} / \mathrm{L}$ & $15 \mathrm{mg} / \mathrm{L}$ \\
\hline $0-3$ & $9.8 \pm 2.2$ & $6.6 \pm 0.6$ & $6.4 \pm 1.1$ & $5.7 \pm 0.9$ \\
\hline $3-7$ & $4.8 \pm 2.2$ & $7.3 \pm 1.7$ & $5.8 \pm 1.0$ & $5.0 \pm 1.7$ \\
\hline $7-11$ & $1.3 \pm 0.5$ & $5.3 \pm 2.5$ & $1.2 \pm 0.5$ & $7.6 \pm 0.2$ \\
\hline $11-14$ & $2.6 \pm 1.4$ & $7.7 \pm 1.5$ & $1.7 \pm 2.6$ & $8.1 \pm 1.9$ \\
\hline $14-21$ & $3.0 \pm 0.4$ & $2.5 \pm 0.4$ & $6.4 \pm 1.5$ & $7.4 \pm 0.1$ \\
\hline $21-27$ & $6.5 \pm 1.4$ & $4.5 \pm 1.7$ & $6.4 \pm 0.5$ & $3.8 \pm 0.6$ \\
\hline $27-29$ & $19.6 \pm 3.3$ & $19.2 \pm 6.0$ & $11.5 \pm 4.6$ & $5.5 \pm 1.2$ \\
\hline $29-34$ & $11.9 \pm 0.9$ & $10.6 \pm 1.4$ & $9.2 \pm 1.5$ & $0.1 \pm 1.9$ \\
\hline $34-38$ & $8.2 \pm 1.6$ & $18.4 \pm 1.3$ & $19.6 \pm 0.6$ & $1.0 \pm 3.2$ \\
\hline $38-41$ & & $11.4 \pm 0.5$ & $10.1 \pm 0.7$ & $0.6 \pm 7.3$ \\
\hline $41-44$ & & $10.3 \pm 0.6$ & $6.7 \pm 1.1$ & $-2.2 \pm 4.9$ \\
\hline $44-47$ & & & $8.9 \pm 5.1$ & $1.3 \pm 3.8$ \\
\hline $47-50$ & & & $5.5 \pm 4.0$ & $1.2 \pm 4.0$ \\
\hline $50-54$ & & & $11.4 \pm 0.9$ & $-1.3 \pm 3.7$ \\
\hline $54-58$ & & & $12.8 \pm 1.1$ & $-0.7 \pm 2.4$ \\
\hline $58-62$ & & & $7.8 \pm 2.0$ & $1.0 \pm 1.9$ \\
\hline
\end{tabular}


Table 2. Average naproxen degradation rates by immobilized cells of Planococcus sp. S5. Data presented as a mean \pm standard deviation of three replicates.

\begin{tabular}{|c|c|c|c|c|}
\hline \multirow{2}{*}{ Period [Day-Day] } & \multicolumn{4}{|c|}{ Average Naproxen Degradation Rate $[\mu \mathrm{g} / \mathrm{h}]$} \\
\hline & $6 \mathrm{mg} / \mathrm{L}$ & $9 \mathrm{mg} / \mathrm{L}$ & $12 \mathrm{mg} / \mathrm{L}$ & $15 \mathrm{mg} / \mathrm{L}$ \\
\hline $0-4$ & $11.2 \pm 1.2$ & $20.7 \pm 8.6$ & $16.1 \pm 6.7$ & $13.9 \pm 0.6$ \\
\hline $4-8$ & $13.9 \pm 0.9$ & $10.1 \pm 1.4$ & $18.0 \pm 14.6$ & $10.5 \pm 2.5$ \\
\hline $8-13$ & $15.8 \pm 1.1$ & $12.9 \pm 1.8$ & $13.2 \pm 5.4$ & $13.4 \pm 4.2$ \\
\hline $13-17$ & $18.2 \pm 1.7$ & $6.4 \pm 2.4$ & $10.1 \pm 1.2$ & $10.0 \pm 1.4$ \\
\hline $17-21$ & & $11.6 \pm 3.0$ & $9.4 \pm 0.9$ & $10.0 \pm 1.0$ \\
\hline $21-25$ & & $15.0 \pm 5.8$ & $12.0 \pm 4.8$ & $4.6 \pm 4.2$ \\
\hline $25-29$ & & $7.6 \pm 3.9$ & $5.1 \pm 0.6$ & $9.7 \pm 5.6$ \\
\hline $29-32$ & & $8.7 \pm 4.2$ & $6.4 \pm 2.9$ & $13.1 \pm 5.6$ \\
\hline $32-36$ & & & $11.5 \pm 1.7$ & $10.8 \pm 6.0$ \\
\hline $36-39$ & & & $17.4 \pm 4.8$ & $9.4 \pm 4.3$ \\
\hline $39-43$ & & & $7.3 \pm 2.4$ & $13.0 \pm 2.5$ \\
\hline $43-46$ & & & & $19.0 \pm 2.8$ \\
\hline $46-49$ & & & & $17.7 \pm 0.6$ \\
\hline $49-53$ & & & & $14.6 \pm 2.2$ \\
\hline
\end{tabular}

It is known that one of the most important parameters that can significantly affect the biodegradation process is initial substrate concentration. Analysis of the patterns and correlations between the time of incubation, naproxen concentration and biodegradation rate shows that free cells of Planococcus sp. S5 were capable of the fastest biodegradation of naproxen at the lowest dose. With increasing drug concentration the rate of naproxen biodegradation was decreased (Figure 3a). Obtained results indicated that during decomposition of naproxen, accumulation of metabolites occurred, which negatively affect free cells of S5 strain and caused increasing difficulties with its total degradation. Therefore, biodegradation of the highest dose of naproxen $(15 \mathrm{mg} / \mathrm{L})$ ended with $29 \%$ efficiency most likely due to the critical level of inhibitory or toxic metabolites. Recently, more attention has been focused on the antibacterial activity of certain NSAIDs or their derivatives [38,39]. Although the mechanisms of this process are not known, one study found that vedaprofen, bromfenac and carprofen-by binding to polymerase $\alpha$ subunit-inhibit the proliferation of E. coli, A. baylyi, S. aureus and $B$. subtilis cells [39]. Inhibitory effect of naproxen on the ammonia oxidizing bacterium (AOB) Nitrosomonas europaea was observed by Wang et al. [40]. They revealed that naproxen at concentration of $10 \mu \mathrm{M}$ significantly inhibits nitrile production by AOB by affecting membrane integrity of the cells, while exposure on the drug in concentration of $1 \mu \mathrm{M}$ did not influences AOB cells. To reveal possibility of antibacterial activity of naproxen or its intermediates on Planococcus S5 cells more research should be attempted.

No correlation between analysed variables was observed for the immobilized cells. Degradation proceeded with the same trend regardless of the initial naproxen concentration (Figure 3b). Obtained results indicated good adaptation of immobilized S5 cells to the presence of higher concentrations of naproxen. Lack of the lag phase and concentration-independent drug biodegradation course suggests that formed biofilm reduced the sensitivity of the cells to naproxen and its intermediates. Due to the good sorption properties and the limited diffusion in the extracellular biofilm matrix, immobilized microorganisms have limited contact with xenobiotics, which are transported to the cells at a constant, slower rate. This mechanism allows the immobilized cells to biodegrade higher concentrations of impurities, without causing toxic effects [41]. Thus, the immobilized cells of Planococcus sp. S5 onto the loofah sponge have a promising potential to use them for the bioremediation of naproxen-contaminated sites. In addition, lack of the toxic effect of naproxen and its metabolites on immobilized cells allowed them to utilize higher concentrations of the drug compared to the free cells. 


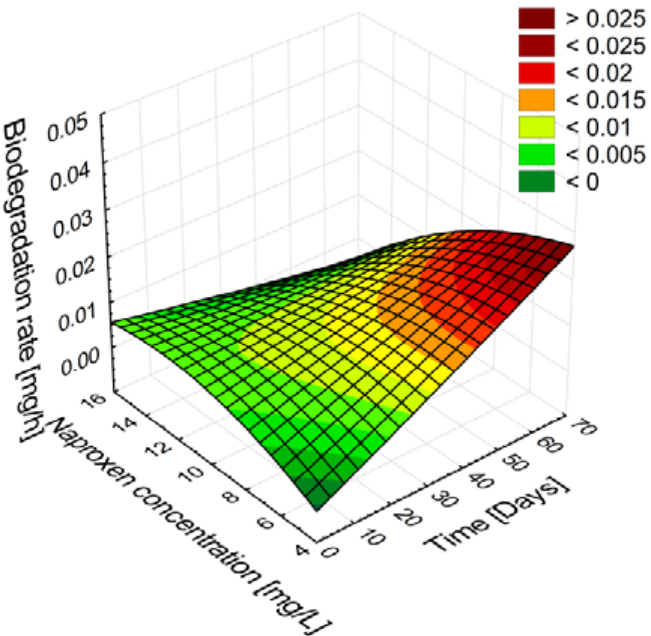

(a)

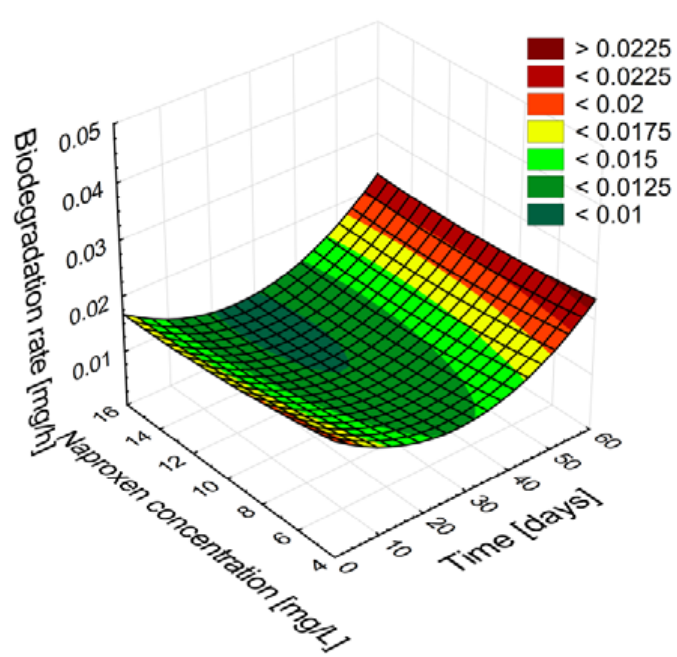

(b)

Figure 3. Naproxen (6, 9, 12 and $15 \mathrm{mg} / \mathrm{L})$ biodegradation rate by (a) free cells of Planococcus sp. S5; and (b) immobilized on loofah sponges cells of Planococcus sp. S5; presented as patterns and the relationships among the time of incubation, naproxen concentration and biodegradation rate.

\subsubsection{Stability and Degradation Capacity of the Developed Whole-Cell Biocatalyst System}

The stability during long-term operations is a crucial factor for practical application of immobilized biocatalysts. To test reusability of Planococcus sp. S5 cells immobilized on the loofah sponges, the efficiency of naproxen biodegradation in subsequent cycles has been determined. In the presence of fresh sterile mineral salts medium in each cycle, immobilized cells were able to complete drug degradation in 3 repetitions (Figure 4). The first and the second dose of naproxen were utilized within respectively 17 and 15 days. In the next cycle it was observed deceleration of the degradation efficiency (21 days) while in the 4th cycle, the biodegradation ended after decomposition of $27 \%$ of the drug. However, cells of Planococcus sp. S5 immobilized on loofah sponges demonstrated the ability to efficient naproxen biodegradation for 55 days. After the end of the experiment, no significant damage and disintegration of the loofah sponges was observed, which confirms its high mechanical resistance [14].

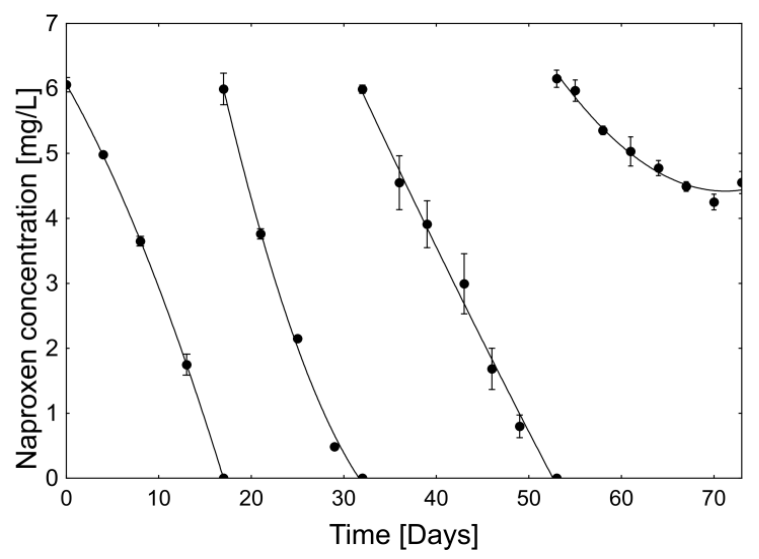

Figure 4. Cycles of $6 \mathrm{mg} / \mathrm{L}$ naproxen degradation by immobilized Planococcus sp. S5 on the loofah sponge. Data presented as a mean \pm standard deviation of three replicates.

Evaluation of the biodegradation rate during each cycle shows not significant differences in the first 3 cycles of naproxen biodegradation amounting $14.8 \pm 3.0,16.0 \pm 6.9$ and $11.4 \pm 3.9 \mu \mathrm{g} / \mathrm{h}$ respectively (Table 3, Figure 5). Only during the first cycle it was observed increasing rate of 
drug degradation. The second and third cycle, however, were characterized by slowing down biodegradation rate, while the last one proceeded unstable (Table 3). It is suggested that one of the reasons why immobilization extends the catalytic activity of cells is to ensure the stability of cell membranes and adequate permeability [41].

Table 3. Average biodegradation rate of $6 \mathrm{mg} / \mathrm{L}$ naproxen by immobilized cells of Planococcus sp. S5 in each cycle. Data presented as a mean \pm standard deviation of three replicates. Different letters $(a, b, c)$ indicate a statistically significant difference between biodegradation rates during subsequent cycles $(p \geq 0.05)$.

\begin{tabular}{|c|c|c|c|c|}
\hline \multirow{2}{*}{ Period [Day-Day] } & \multicolumn{4}{|c|}{ Average Naproxen Degradation Rate $[\mu \mathrm{g} / \mathrm{h}]$} \\
\hline & I Cycle & II Cycle & III Cycle & IV Cycle \\
\hline $0-4$ & $11.2 \pm 1.2^{\mathrm{a}}$ & & & \\
\hline $4-8$ & $13.9 \pm 0.9^{b}$ & & & \\
\hline $8-13$ & $15.8 \pm 1.1^{b}$ & & & \\
\hline $13-17$ & $18.2 \pm 1.7^{\mathrm{c}}$ & & & \\
\hline $17-21$ & & $23.2 \pm 1.8^{\mathrm{a}}$ & & \\
\hline $21-25$ & & $16.8 \pm 0.7^{b}$ & & \\
\hline $25-29$ & & $17.4 \pm 0.2^{b}$ & & \\
\hline $29-32$ & & $6.7 \pm 0.1^{\mathrm{c}}$ & & \\
\hline $32-36$ & & & $15.0 \pm 3.8^{\mathrm{a}}$ & \\
\hline $36-39$ & & & $8.9 \pm 1.4^{b}$ & \\
\hline $39-43$ & & & $9.6 \pm 1.2^{b}$ & \\
\hline $43-46$ & & & $18.2 \pm 2.0^{\mathrm{a}}$ & \\
\hline $46-49$ & & & $12.3 \pm 2.4^{\mathrm{ab}}$ & \\
\hline $49-53$ & & & $8.3 \pm 1.8^{b}$ & \\
\hline $53-55$ & & & & $3.8 \pm 3.5^{\mathrm{a}}$ \\
\hline $55-58$ & & & & $8.5 \pm 3.2^{b}$ \\
\hline $58-61$ & & & & $6.8 \pm 0.1^{\mathrm{ab}}$ \\
\hline 61-64 & & & & $3.5 \pm 1.7^{a}$ \\
\hline $64-67$ & & & & $3.9 \pm 1.0^{\mathrm{a}}$ \\
\hline $67-70$ & & & & $3.3 \pm 1.9^{a}$ \\
\hline $70-73$ & & & & $-4.2 \pm 2.5^{c}$ \\
\hline
\end{tabular}

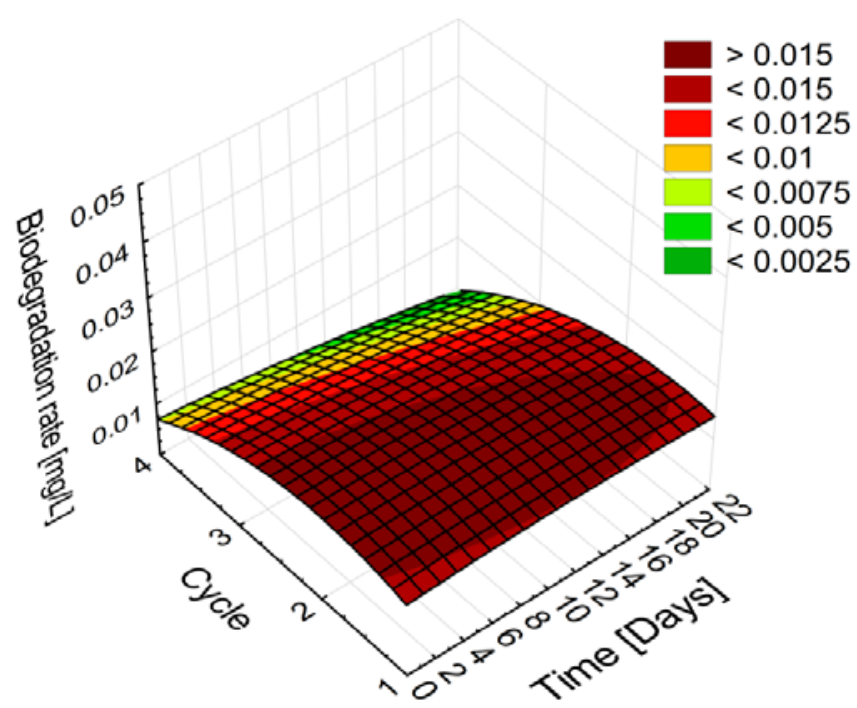

Figure 5. Naproxen $(6 \mathrm{mg} / \mathrm{L})$ biodegradation rate during subsequent cycles by immobilized on loofah sponges cells of Planococcus sp. S5 presented as patterns and the relationships among the time of incubation, cycle and biodegradation rate. 
The ability of immobilized cells of Planococcus sp. S5 to carry out the biodegradation of naproxen in several cycles indicates the possibility of their use in bioremediation. However, to study their behaviour in such systems it is necessary to conduct pilot studies.

\subsection{The Influence of Immobilization on Enzymes Activity}

The process of biodegradation of naproxen by white rot fungi is much better understood than by bacteria $[29,42-44]$. One of the proposed mechanisms demonstrates naproxen demethylation carried out by cytochrome P-450 [32]. The reaction product, 6-desmethylnaproxen appeared during biodegradation of naproxen by the Planococcus sp. S5 strain. Domaradzka et al. [2] showed that some enzymes involved in the degradation of polycyclic aromatic hydrocarbons were active during cometabolic (with glucose) biodegradation of naproxen by free cells of Planococcus sp. S5. The activity of phenol monooxygenase, naphthalene dioxygenase, hydroxyquinol 1,2-dioxygenase and gentisate 1,2-dioxygenase was demonstrated.

A typical degradation pathway of aromatic compounds by bacteria is the initial hydroxylation followed by the ring cleavage [45]. The first step in degradation of naphthalene (the derivative of which is naproxen) is the hydroxylation of $\mathrm{C} 1$ and $\mathrm{C} 2$ catalysed by naphthalene dioxygenase [46]. It was suggested that this enzyme is responsible for hydroxylation of $\mathrm{C} 7$ and $\mathrm{C} 8$ of naproxen. Moreover, on the base of the activity of phenol monooxygenase additional hydroxylation was proposed. Formed trihydroxylated derivative probably is cleaved by hydroxyquinol 1,2-dioxygenase [2]. One of the most important steps in catabolism of naphthalene is its conversion to salicylate, which bacterial pathway has been well described. The most important part of the catabolism of salicylate is direct ring cleavage by salicylate 1,2-dioxygenase or gentisate 1,2-dioxygenase (in case salicylate transformation to gentisate by monooxygenase). The salicylate transformation products are next introduced into the tricarboxylic acid cycle [47-49].

Because the immobilization of bacterial cells may change the xenobiotic degradation pathway, the activity of enzymes that are involved in naproxen degradation were examined. This phenomenon is related to the change in the gene expression profile that occurs during the formation of the biofilm and can be related to the type of carrier surface [50,51].

The activities of $O$-demethylase, aromatic monooxygenase (with phenol or naproxen as a substrate), naphthalene dioxygenase, gentisate 1,2-dioxygenase and salicylate 1,2-dioxygenase were compared. As is shown in Table 4, the activity of all analysed enzymes was observed, both in free and immobilized cells. Obtained results showed that the naproxen biodegradation pathway in immobilized S5 cells probably did not change markedly. Significant changes, however, were observed in the values of activity (Table 4). As expected, during the slower degradation phase of naproxen (15th day), free S5 cells were characterized by the lowest activity of enzymes associated with drug degradation. At the same time, the enzymatic activity of immobilized cells was about 2 times higher in the case of $\mathrm{O}$-demethylase, aromatic monooxygenase (with phenol as a substrate), naphthalene dioxygenase and salicylate 1,2-dioxygenase. Interesting increase in the activity of aromatic monooxygenase (with naproxen as a substrate, 10 times higher) and gentisate 1,2-dioxygenase (4 times higher) was observed in the immobilized cells. However, due to the methodology for determining the activity of aromatic monooxygenase (determination of reduced nicotinamide adenine dinucleotide - NADH oxidation), it is not excluded that more of the enzymes belonging to the class of oxidoreductases are involved in the degradation of naproxen by immobilized cells of Planococcus sp. S5. A higher gentisate 1,2-dioxygenase activity may have been caused by the increase of its participation (in relation to salicylate 1,2-dioxygenase) in the drug biodegradation due to immobilization.

Due to the non-statistically different biodegradation rate of naproxen by free cells in the phase of faster drug degradation and immobilized cells, it was suspected that the enzymatic activity of these systems would also not be different. However, according to the analysis (Table 4), the activity of all analysed enzymes was higher in the immobilized cells. Higher activity of enzymes associated with the biodegradation of naproxen in immobilized cells confirms that the sensitivity to the drug of cells in the 
developed biocatalyst was reduced. For that reason, the significant acceleration of its biodegradation was observed.

Table 4. Specific activity of enzymes involved in naproxen degradation under cometabolic conditions by immobilized and non-immobilized Planococcus sp. S5. Different letters (a, b, c) indicate a statistically significant difference between activity of enzymes from free and immobilized cells $(p \geq 0.05)$.

\begin{tabular}{|c|c|c|c|}
\hline \multirow{3}{*}{ Enzyme } & \multicolumn{3}{|c|}{$\begin{array}{l}\text { Specific Enzyme Activity } \\
\text { (U/mg protein) }\end{array}$} \\
\hline & \multicolumn{2}{|c|}{ Free Cells } & \multirow{2}{*}{$\begin{array}{c}\text { Immobilized Cells } \\
\text { 15th Day }\end{array}$} \\
\hline & 15th Day & 35th Day & \\
\hline O-demethylase & $412.84 \pm 48.53^{\mathrm{a}}$ & $737.16 \pm 55.81^{b}$ & $1051.84 \pm 65.57^{\mathrm{c}}$ \\
\hline $\begin{array}{c}\text { Aromatic } \\
\text { monooxygenase (Phe) }\end{array}$ & $13.06 \pm 0.83^{\mathrm{a}}$ & $27.14 \pm 2.40^{\mathrm{b}}$ & $31.55 \pm 1.18^{c}$ \\
\hline $\begin{array}{c}\text { Aromatic } \\
\text { monooxygenase (Npx) }\end{array}$ & $14.78 \pm 1.28^{a}$ & $65.17 \pm 3.59^{b}$ & $123.71 \pm 12.39^{c}$ \\
\hline $\begin{array}{l}\text { Naphthalene } \\
\text { dioxygenase }\end{array}$ & $8.16 \pm 0.82^{\mathrm{a}}$ & $10.71 \pm 2.23^{\mathrm{a}}$ & $15.73 \pm 1.80^{b}$ \\
\hline $\begin{array}{c}\text { Gentisate } \\
\text { 1,2-dioxygenase }\end{array}$ & $52.95 \pm 2.90^{\mathrm{a}}$ & $122.26 \pm 9.44^{b}$ & $203.03 \pm 18.55^{c}$ \\
\hline $\begin{array}{c}\text { Salicylate } \\
\text { 1,2-dioxygenase }\end{array}$ & $388.26 \pm 11.12^{a}$ & $520.38 \pm 24.60^{b}$ & $714.87 \pm 71.58^{c}$ \\
\hline
\end{tabular}

\subsection{Changes in Biofilm Formed Onto the Loofah Sponge during Naproxen Degradation}

Visualization of bacterial biofilm in high resolution using SEM (Scanning Electron Microscopy) is one of the best methods to determine the biofilm structure. Preparation of samples for analysis by SEM involves the fixation of their structures (using glutaraldehyde and osmium tetraoxide), dewatering, drying and covering with a conductive layer. However, due to the fact that the structure of EPS (which stability is dependent on the presence of water) often collapses during dewatering and drying, identifying certain structures in biofilm sometimes is problematic [52]. The procedure of sample preparation very often leads to the creation of artefacts. One of them, especially at higher magnifications, is the appearance of EPS as fibres or granularity and not as a gel structure surrounding the cells [53]. However, the advantage of this visualization method is the possibility of determining the distribution of microorganisms and changes in the biofilm structure caused by specific factors. Considering the identical preparation of samples for analysis, demonstration of changes in the biofilm structure in relation to the state of biofilm before exposure to a specific factor reduces the probability of incorrect image analysis.

Loofah sponge which was used as a carrier for immobilization, observed in SEM revealed its multidirectional highly fibrous network and porous surface with a small protuberances (Figure 6a) which was a suitable place for the attachment of microorganisms.

After immobilization of Planococcus sp. S5 cells through the adsorption on the surface (lasting $72 \mathrm{~h}$ ), accumulation of cells covered with an extracellular matrix (Figure 6b) was observed. Flat biofilm formed on the loofah sponges had the form of irregular rods of different lengths (Figure 6b) and appeared in aggregates.

When the first and the second dose of naproxen $(6 \mathrm{mg} / \mathrm{L})$ have been degraded (respectively $17 \mathrm{th}$ and 36th day of incubation), immobilized loofah sponges were observed in SEM to reveal changes in biofilm structure during naproxen biodegradation. After complete degradation of the first dose of naproxen, a more diversified and intense colonization of the carrier was observed (Figure 6c). There was present formation of the connections between aggregates (Figure 6c) and new fibrous extracellular matrix-like structures. When the second dose of naproxen was degraded, surface of loofah sponges was completely covered by biofilm formed by Planococcus sp. S5 (Figure 6d). A decrease in the amount of aggregates in relation to the newly formed structures was observed. 
In the presence of toxic substances bacteria trigger different protective mechanisms. One of them is the secretion of large amounts of EPS, which will create a protective layer for cells. At the same time, by forming clusters, the cells reduce the contact surface with the toxin-containing environment [54]. Due to the problematic utilization of naproxen by free S5 cells (especially in the first phase of degradation), increased tolerance of immobilized cells appears to be the result of the accumulation of large amounts of extracellular substances in the biofilm. The same defence mechanism was observed by Ma et al. [55] against to immobilized bacteria from activated sludge during biodegradation of phenol. They showed that with the increase in the amount of toxic phenol nol photodegradation products, the number of microbial cells in the biofilm decreased. On the other hand, the amount of secreted EPS was increasing, which resulted with a lack of differences in the phenol biodegradation way.

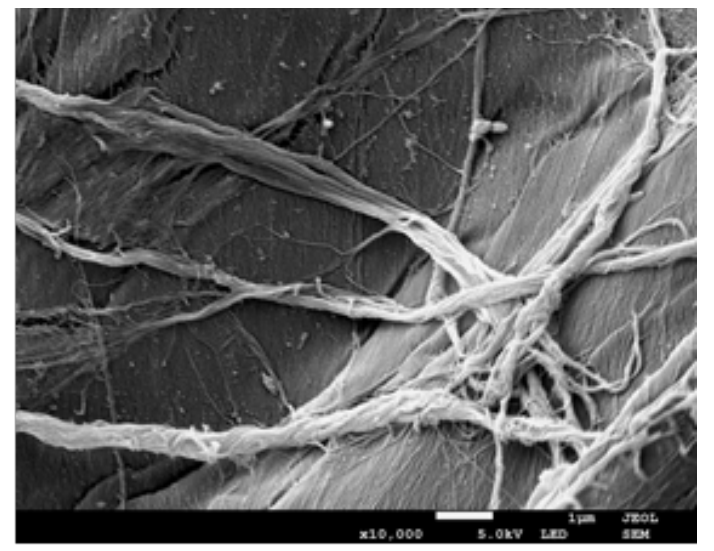

(a)

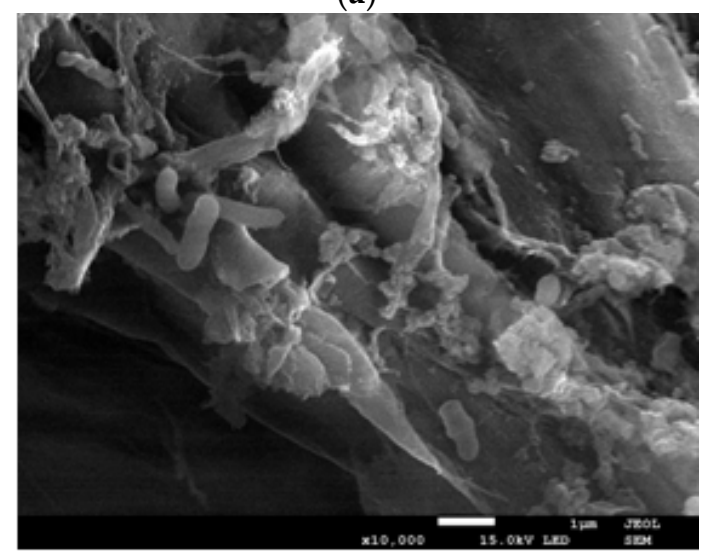

(c)

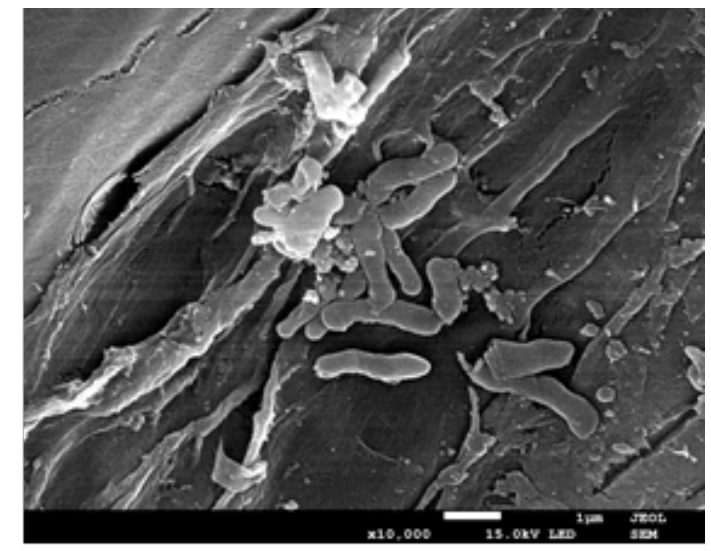

(b)

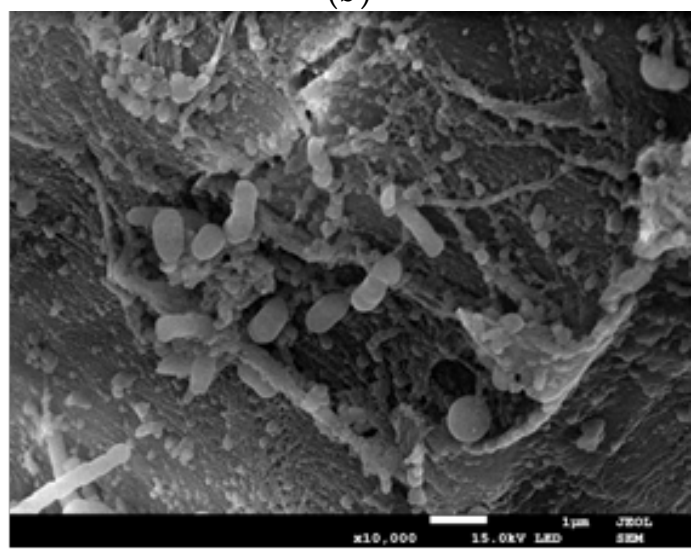

(d)

Figure 6. Scanning electron microscopy (SEM) micrographs of unimmobilized loofah sponge (a), biofilm formed by Planococcus sp. S5 cells onto loofah sponge before naproxen degradation (b), after decomposition of the first dose of naproxen $(6 \mathrm{mg} / \mathrm{L})(\mathbf{c})$ and the second dose of the drug $(6 \mathrm{mg} / \mathrm{L})(\mathbf{d})$.

\section{Materials and Methods}

\subsection{Bacterial Cultures Cultivation}

Isolated from activated sludge Gram-positive strain Planococcus sp. S5 described by Łabużek et al. [21] was used. Proliferation of S5 cells was carried out in the nutrient broth (BBL) at $30{ }^{\circ} \mathrm{C}$ on a rotary shaker at $130 \mathrm{rpm}$. After $72 \mathrm{~h}$ of incubation bacterial cultures were centrifuged ( $5000 \mathrm{rpm}, 15 \mathrm{~min}$ ), washed twice with mineral salts medium [56] and resuspended in the same medium. Prepared bacterial suspensions were used as an inoculum for immobilization and control non-immobilized cells experiments. 


\subsection{Carrier Preparation for Immobilization}

The first step in the preparation of the loofah sponges (York, Bolechowo, Poland) for immobilization was drying them in a desiccator to establish constant weight and cutting out fragments weighing $0.15 \mathrm{~g}$. Obtained cubes were washed according to Iqbal et al. [14] and sterilized $\left(121{ }^{\circ} \mathrm{C}\right.$, $1.2 \mathrm{~atm})$ two times at an interval of $24 \mathrm{~h}$.

\subsection{Immobilization Procedure}

Cells of S5 strain were immobilized through the adsorption on the surface of loofah sponge. Immobilization was conducted in $250 \mathrm{~mL}$ Erlenmeyer flasks, which contained $0.75 \mathrm{~g}$ of the carrier and $100 \mathrm{~mL}$ of the mineral salts medium (pH 7.2) with Planococcus sp. S5 cells (optical density at $600 \mathrm{~nm}$ equal to 1.2; Genesys 20, Thermo Scientific). Medium was supplemented with glucose ( $0.5 \mathrm{~g} / \mathrm{L}), \mathrm{NaCl}$ $(10 \mathrm{~g} / \mathrm{L})$ and $\mathrm{MnSO}_{4}(0.01 \mathrm{~g} / \mathrm{L})$. Flasks were incubated with shaking $(90 \mathrm{rpm})$, at temperature of $30^{\circ} \mathrm{C}$. After $72 \mathrm{~h}$ of incubation, loofah sponges with immobilized bacteria were rinsed with aqueous solution of $\mathrm{NaCl}(0.9 \%)$ to remove unbound microorganisms and used for biodegradation experiments.

\subsection{Characterization of Immobilized Loofah Sponges}

Dry mass of the immobilized bacteria was obtained by comparing the dried weight of immobilized carrier $\left(105^{\circ} \mathrm{C}, 2 \mathrm{~h}\right.$ and stored in a desiccator) with unimmobilized carriers incubated and dried under the same conditions. Enzymatic activity of biofilm formed onto loofah sponge was measured as follow (modified method proposed by Jiang et al. [19]): immobilized carrier (1 cube) was added to $8 \mathrm{~mL}$ of phosphate buffer ( $\mathrm{pH} 7.6$ ) and incubated for $15 \mathrm{~min}$ on the orbital shaker $\left(130 \mathrm{rpm}, 30^{\circ} \mathrm{C}\right)$. After pre-incubation, $0.1 \mathrm{~mL}$ of FDA (Sigma-Aldrich, St. Louis, MO, USA) $\left(4.8 \mathrm{mmol} \mathrm{L}{ }^{-1}\right)$ was slowly injected directly into middle of the carrier and incubated in the dark on the orbital shaker $(130 \mathrm{rpm}$, $30^{\circ} \mathrm{C}$ ) for $1 \mathrm{~h}$. Fluorescence intensity in the liquid was measured spectrophotometrically at $490 \mathrm{~nm}$ (Genesys 20, Thermo Scientific, Waltham, MA, USA). Concentration of fluorescein was calculated on the basis of a standard curve.

\subsection{Biodegradation Experiments}

Naproxen decomposition was conducted in $500 \mathrm{~mL}$ Erlenmeyer flask containing $250 \mathrm{~mL}$ of the mineral salts medium [56] and 10 pieces of the loofa sponge colonized by bacteria. Each flash was supplement with naproxen (Sigma-Aldrich, USA) to obtain a final concentration of 6, 9, 12 or $15 \mathrm{mg} / \mathrm{L}$ and at every 3 days with glucose $(0.5 \mathrm{~g} / \mathrm{L}, \mathrm{POCH}$, Gliwice, Poland $)$ and incubated with shaking $(130 \mathrm{rpm})$ at $30^{\circ} \mathrm{C}$. The control cultures contained non-immobilized cells of Planococcus sp. S5 were also prepared. For estimation of naproxen accumulation in the biofilm the drug extraction with modified Huerta et al. protocol was performed [36]. Loofah sponges with immobilized bacteria were cut into small pieces and placed in $15 \mathrm{~mL}$ falcon tube with $10 \mathrm{~mL}$ of mixture of citric buffer ( $\mathrm{pH} 4)$ and acetonitrile (1:1, v/v, Sigma-Aldrich, USA). Mixtures were subsequently sonicated 3 times for $10 \mathrm{~min}$ and centrifuged (15,000 rpm, $20 \mathrm{~min})$. Obtained supernatants were analysed by HPLC and naproxen concentrations were calculated based on a standard curve prepared with extraction mixture. Determination of naproxen adsorption on the carrier was conducted by incubation sterile loofah sponges $(1.5 \mathrm{~g})$ with $250 \mathrm{~mL}$ of MSM medium supplemented with naproxen $(6 \mathrm{mg} / \mathrm{L})$ and glucose $(0.5 \mathrm{~g} / \mathrm{L})$ in $500 \mathrm{~mL}$ Erlenmeyer flasks. Medium samples were taken every $24 \mathrm{~h}$ for 7 days and analysed by HPLC to determine naproxen concentration.

\subsection{Determination of Naproxen Concentration}

Decomposition of naproxen was monitored by HPLC (Merck HITACHI, Darmstadt, Germany) equipped with a LiChromospher ${ }^{\circledR}$ RP-18 column $(4 \times 250 \mathrm{~mm})$, liChroCART ${ }^{\circledR} 250-4$ Nucleosil 5 C18 and a DAD detector (Merck HITACHI). Medium samples from each flask were taken at 3 days period and centrifuged $(14,000 \mathrm{rpm}, 20 \mathrm{~min})$. Naproxen identification and quantification in the supernatant 
was done by following the protocol proposed by Wojcieszyńska et al. [32]. The mobile phase consisted acetonitrile and $1 \%$ acetic acid $(50: 50 \mathrm{v} / \mathrm{v})$ with a flow rate of $1 \mathrm{~mL} / \mathrm{min}$ and column temperature was $23{ }^{\circ} \mathrm{C}$. The detection wavelength was set at $260 \mathrm{~nm}$. Naproxen was identified by way of comparison of HPLC retention time $(2.41 \mathrm{~min})$ and ultraviolet-visible spectra with those of the external standards. To determine the abiotic degradation of naproxen, uninoculated controls were prepared.

\subsection{Enzyme Assay}

After 15 days of incubation (additionally free cells after 35 days), free and immobilized cells of Planococcus sp. S5 were separated from the medium by centrifugation $\left(4500 \times g\right.$ for 15 min at $\left.4{ }^{\circ} \mathrm{C}\right)$. The release of immobilized cells from the carrier was carried out by vortexing. The obtained pellet was washed with $50 \mathrm{mM}$ phosphate buffer ( $\mathrm{pH} 7.0$ ), disrupted by sonication (6 times for $15 \mathrm{~s}$ ) and centrifuged at $9000 \times g$ for $30 \mathrm{~min}$ at $4{ }^{\circ} \mathrm{C}$. Obtained crude extract was used for the measurement of enzyme activities.

The activity of $O$-demethylase was determined by measuring the loss of vanillic acid $(\lambda=260 \mathrm{~nm})$ with the use of the HPLC method [57]. In order to determine monooxygenase activity (with phenol or naproxen as a substrate), NADH oxidation $\left(\varepsilon_{340}=6220 / \mathrm{M} \mathrm{cm}\right)$ was measured spectrophotometrically [58]. The naphthalene dioxygenase, gentisate 1,2-dioxygenase and salicylate 1,2-dioxygenase activity was measured spectrophotometrically by the formation of cis,cis-dihydrodiol $\left(\varepsilon_{262}=8230 / \mathrm{M} \mathrm{cm}\right)$ [46], maleylpyruvate $\left(\varepsilon_{330}=10,800 / \mathrm{M} \mathrm{cm}\right)$ [49] and 2-oxohepta-3,5-dienedioic acid $\left(\varepsilon_{283}=13,600 / \mathrm{M} \mathrm{cm}\right)$ [48], respectively. Protein concentration was determined using the Bradford method [59]. One unit of enzyme activity was defined as the amount of enzyme required to generate $1 \mu \mathrm{mol}$ of product per minute.

\subsection{Scanning Electron Microscopy}

To observe the structure of biofilm formed onto the loofah sponges and its changes during naproxen biodegradation, samples for Scanning Electron Microscopy were prepared. For this examination, unimmobilized and immobilized loofah sponges before and after naproxen biodegradation were collected from the medium and prepared as follows: fixation in $3 \%$ glutaraldehyde $(24 \mathrm{~h})$, in $1 \%$ osmium tetroxide ( $3 \mathrm{~h}$ ), dehydration with ethanol (30, 50, 70, 80, 90,95 and 100\%, each for $10 \mathrm{~min}$ ), drying by lyophilisation and covering with gold. Samples were observed in high-resolution electron microscope JSM-7100F TTL LV (JEOL, Tokio, Japan).

\subsection{Statistical Analysis}

All experiments were performed in at least three replicates. The values of the efficiency of naproxen biodegradation and enzymes activities were analysed by STATISTICA 12 PL software package. Statistically significant differences and similarities have been demonstrated by the $t$-test or the Least Significant Differences (LSD) test ( $p \geq 0.05)$.

\section{Conclusions}

Ability of some bacterial strains to form a biofilm on the surface of various materials is a key element for efficient immobilization process. By optimizing each parameter of the immobilization procedure, a biocatalyst that is characterized by increased naproxen biodegradation capacities has been developed. Immobilized cells of Planococcus sp. S5 strain on the loofah sponge, compared to the free cells, were able to faster biodegradation of naproxen added at higher doses. Additionally, due to the maintenance of full catalytic activity for 3 cycles (55 days), immobilized onto the loofah sponge S5 cells, show promising potential in their application in bioremediation systems. Analysis of the effect of immobilization on the activity of enzymes associated with naproxen biodegradation showed that it caused a significant increase in the activity of all examined enzymes. The significant increase in the efficiency of the naproxen biodegradation by immobilized S5 cells was most probably caused by the synthesis of large amounts of EPS, which by sorption and limitation of the substrates diffusion increased the tolerance of the strain to the drug. 
Supplementary Materials: The following are available online at http://www.mdpi.com/2073-4344/8/5/176/s1, Figure S1: Effect of various environmental and physiological factors on the efficiency of Planococcus sp. S5 cells immobilization onto the loofah sponge.

Author Contributions: A.D. conceived, designed and performed the experiment, analysed the data and wrote the paper; D.W. analysed the data and wrote the paper; K.H.-K. corrected manuscript, M.A.-H. contribution in analysis of SEM micrographs, U.G. designed the experiment, analysed the data and wrote the paper.

Acknowledgments: This work was financed by the National Science Centre (Poland), granted on the basis of decision DEC-2017/25/N/NZ9/00422. We are grateful to Jolanta Dzik for help with preparing SEM micrographs.

Conflicts of Interest: The authors declare no conflict of interest.

\section{References}

1. Wojcieszyńska, D.; Domaradzka, D.; Hupert-Kocurek, K.; Guzik, U. Enzymes Involved in Naproxen Degradation by Planococcus sp. S5. Pol. J. Microbiol. 2016, 1, 177-182. [CrossRef]

2. Domaradzka, D.; Guzik, U.; Hupert-Kocurek, K.; Wojcieszyńska, D. Cometabolic degradation of naproxen by Planococcus sp. strain S5. Water Air Soil Pollut. 2015, 226, 297. [CrossRef] [PubMed]

3. Grenni, P.; Patrolecco, L.; Ademollo, N.; Tolomei, A.; Caracciolo, A.B. Degradation of gemfibrozil and naproxen in a river water ecosystem. Microchem. J. 2013, 107, 158-164. [CrossRef]

4. Marotta, R.; Spasiano, D.; Di Somma, I.; Andreozzi, R. Photodegradation of naproxen and its photoproducts in aqueous solution at $254 \mathrm{~nm}$ : A kinetic investigation. Water Res. 2013, 47, 373-383. [CrossRef] [PubMed]

5. Musa, K.A.; Eriksson, L.A. Theoretical study of the phototoxicity of naproxen and the active form of nabumetone. J. Phys. Chem. A 2008, 112, 10921-10930. [CrossRef] [PubMed]

6. Isidori, M.; Lavorgna, M.; Nardelli, A.; Parrella, A.; Previtera, L.; Rubino, M. Ecotoxicity of naproxen and its phototransformation products. Sci. Total Environ. 2005, 348, 93-101. [CrossRef] [PubMed]

7. Alvarez, A.; Saez, J.M.; Costa, J.S.D.; Colin, V.L.; Fuentes, M.S.; Cuozzo, S.A.; Amoroso, M.J. Actinobacteria: Current research and perspectives for bioremediation of pesticides and heavy metals. Chemosphere 2017, 166, 41-62. [CrossRef] [PubMed]

8. Dzionek, A.; Wojcieszyńska, D.; Guzik, U. Natural carriers in bioremediation: A review. Electron. J. Biotechnol. 2016, 19, 28-36. [CrossRef]

9. $\mathrm{Xu}, \mathrm{Y}$.; Lu, M. Bioremediation of crude oil-contaminated soil: Comparison of different biostimulation and bioaugmentation treatments. J. Hazard. Mater. 2010, 183, 395-401. [CrossRef] [PubMed]

10. Alessandrello, M.J.; Parellada, E.A.; Tomás, M.S.J.; Neske, A.; Vullo, D.L.; Ferrero, M.A. Polycyclic aromatic hydrocarbons removal by immobilized bacterial cells using annonaceous acetogenins for biofilm formation stimulation on polyurethane foam. J. Environ. Chem. Eng. 2017, 5, 189-195. [CrossRef]

11. Carpentier, B.; Cerf, O. Biofilms and their consequences, with particular reference to hygiene in the food industry. J. Appl. Microbiol. 1993, 75, 499-511. [CrossRef]

12. Bayat, Z.; Hassanshahian, M.; Cappello, S. Immobilization of microbes for bioremediation of crude oil polluted environments: A mini review. Open Microbiol. J. 2015, 9, 48-54. [PubMed]

13. Moreno-Medina, D.A.; Sánchez-Salinas, E.; Ortiz-Hernández, M.L. Removal of methyl parathion and coumaphos pesticides by a bacterial consortium immobilized in Luffa cylindrica. Rev. Int. Contam. Ambient. 2014, 30, 51-63.

14. Iqbal, M.; Saeed, A.; Edyvean, R.G.J.; O'Sullivan, B.; Styring, P. Production of fungal biomass immobilized loofa sponge (FBILS)-discs for the removal of heavy metal ions and chlorinated compounds from aqueous solution. Biotechnol. Lett. 2005, 27, 1319-1323. [CrossRef] [PubMed]

15. Mazmanci, M.A.; Ünyayar, A. Decolourisation of reactive black 5 by Funalia trogii immobilised on Luffa cylindrica sponge. Process Biochem. 2005, 40,337-342. [CrossRef]

16. Picioreanu, C.; Van Loosdrecht, M.C.; Heijnen, J.J. Two-dimensional model of biofilm detachment caused by internal stress from liquid flow. Biotechnol. Bioeng. 2001, 72, 205-218. [CrossRef]

17. Ohashi, A.; Harada, H. Adhesion strength of biofilm developed in an attached-growth reactor. Water Sci. Technol. 1994, 29, 281-288.

18. Stanley, P.M. Factors affecting the irreversible attachment of Pseudomonas aeruginosa to stainless steel. Can. J. Microbiol. 1983, 29, 1493-1499. [CrossRef] [PubMed] 
19. Jiang, S.; Huang, J.; Lu, H.; Liu, J.; Yan, C. Optimisation for assay of fluorescein diacetate hydrolytic activity as a sensitive tool to evaluate impacts of pollutants and nutrients on microbial activity in coastal sediments. Mar. Pollut. Bull. 2016, 110, 424-431. [CrossRef] [PubMed]

20. Fontvieille, D.A.; Outaguerouine, A.; Thevenot, D.R. Fluorescein diacetate hydrolysis as a measure of microbial activity in aquatic systems: Application to activated sludges. Environ. Technol. 1992, 13, 531-540. [CrossRef]

21. Łabużek, S.; Hupert-Kocurek, K.; Skurnik, M. Isolation and characterisation of new Planococcus sp. strain able for aromatic hydrocarbons degradation. Acta Microbiol. Pol. 2003, 52, 395-404. [PubMed]

22. Hupert-Kocurek, K.; Guzik, U.; Wojcieszynska, D. Characterization of catechol 2,3-dioxygenase from Planococcus sp. strain S5 induced by high phenol concentration. Acta Biochem. Pol. 2012, 59, 345-351.

23. Qurashi, A.W.; Sabri, A.N. Bacterial exopolysaccharide and biofilm formation stimulate chickpea growth and soil aggregation under salt stress. Braz. J. Microbiol. 2012, 43, 1183-1191. [CrossRef] [PubMed]

24. Sonenshein, A.L. Control of sporulation initiation in Bacillus subtilis. Curr. Opin. Microbiol. 2000, 3, 561-566. [CrossRef]

25. Gotz, F. Staphylococcus and biofilms. Mol. Microbiol. 2002, 43, 1367-1378. [CrossRef] [PubMed]

26. Li, H.; Liu, Y.H.; Luo, N.; Zhang, X.Y.; Luan, T.G.; Hu, J.M.; Wang, Z.Y.; Wu, P.C.; Chen, M.J.; Lu, J.Q. Biodegradation of benzene and its derivatives by a psychrotolerant and moderately haloalkaliphilic Planococcus sp. strain ZD22. Res. Microbiol. 2006, 157, 629-636. [CrossRef] [PubMed]

27. Romano, I.; Giordano, A.; Lama, L.; Nicolaus, B.; Gambacorta, A. Planococcus rifietensis sp. nov, Isolated from Algal Mat Collected from a Sulfurous Spring in Campania (Italy). Syst. Appl. Microbiol. 2003, 26, 357-366. [CrossRef] [PubMed]

28. Sprott, G.D.; Larocque, S.; Cadotte, N.; Dicaire, C.J.; McGee, M.; Brisson, J.R. Novel polar lipids of halophilic eubacterium Planococcus H8 and archaeon Haloferax volcanii. Biochim. Biophys. Acta 2003, 1633, 179-188. [CrossRef] [PubMed]

29. Marco-Urrea, E.; Pérez-Trujillo, M.; Blánquez, P.; Vicent, T.; Caminal, G. Biodegradation of the analgesic naproxen by Trametes versicolor and identification of intermediates using HPLC-DAD-MS and NMR. Bioresour. Technol. 2010, 101, 2159-2166. [CrossRef] [PubMed]

30. Rodarte-Morales, A.I.; Feijoo, G.; Moreira, M.T.; Lema, J.M. Degradation of selected pharmaceutical and personal care products (PPCPs) by white-rot fungi. World J. Microbiol. Biotechnol. 2011, 27, 1839-1846. [CrossRef]

31. Marchlewicz, A.; Domaradzka, D.; Guzik, U.; Wojcieszyńska, D. Bacillus thuringiensis B1 (2015b) is a Gram-positive bacteria able to degrade naproxen and ibuprofen. Water Air Soil Pollut. 2016, $227,197$. [CrossRef] [PubMed]

32. Wojcieszyńska, D.; Domaradzka, D.; Hupert-Kocurek, K.; Guzik, U. Bacterial degradation of naproxen-Undisclosed pollutant in the environment. J. Environ. Manag. 2014, 145, 157-161. [CrossRef] [PubMed]

33. Lin, B.; Lyu, J.; Lyu, X.J.; Yu, H.Q.; Hu, Z.; Lam, J.C.; Lam, P.K. Characterization of cefalexin degradation capabilities of two Pseudomonas strains isolated from activated sludge. J. Hazard. Mater. 2015, 282, $158-164$. [CrossRef] [PubMed]

34. Ye, C.; Hu, N.; Wang, Z. Experimental investigation of Luffa cylindrica as a natural sorbent material for the removal of a cationic surfactant. J. Taiwan Inst. Chem. Eng. 2013, 44, 74-80. [CrossRef]

35. Demir, H.; Top, A.; Balköse, D.; Ülkü, S. Dye adsorption behaviour of Luffa cylindrica fibres. J. Hazard. Mater. 2008, 153, 389-394. [CrossRef] [PubMed]

36. Huerta, B.; Rodriguez-Mozaz, S.; Nannou, C.; Nakis, L.; Ruhi, A.; Acuña, V.; Barcelo, D. Determination of a broad spectrum of pharmaceuticals and endocrine disruptors in biofilm from a waste water treatment plant-impacted river. Sci. Total Environ. 2016, 540, 241-249. [CrossRef] [PubMed]

37. Flemming, H.C.; Wingender, J.; Szewzyk, U.; Steinberg, P.; Rice, S.A.; Kjelleberg, S. Biofilms: An emergent form of bacterial life. Nat. Rev. Microbiol. 2016, 14, 563-575. [CrossRef] [PubMed]

38. Neeraja, P.; Srinivas, S.; Mukkanti, K.; Dubey, P.K.; Pal, S. 1H-1, 2, 3-Triazolyl-substituted 1, 3, 4-oxadiazole derivatives containing structural features of ibuprofen/naproxen: Their synthesis and antibacterial evaluation. Bioorg. Med. Chem. Lett. 2016, 26, 5212-5217. [CrossRef] [PubMed] 
39. Yin, Z.; Wang, Y.; Whittell, L.R.; Jergic, S.; Liu, M.; Harry, E.; Oakley, A.J. DNA replication is the target for the antibacterial effects of nonsteroidal anti-inflammatory drugs. Chem. Biol. 2014, 21, 481-487. [CrossRef] [PubMed]

40. Wang, S.; Gunsch, C.K. Effects of selected pharmaceutically active compounds on the ammonia oxidizing bacterium Nitrosomonas europaea. Chemosphere 2011, 82, 565-572. [CrossRef] [PubMed]

41. Rahman, R.N.Z.A.; Ghazali, F.M.; Salleh, A.B.; Basri, M. Biodegradation of hydrocarbon contamination by immobilized bacterial cells. J. Microbiol. 2006, 44, 354-359. [PubMed]

42. Lloret, L.; Eibes, G.; Lú-Chau, T.A.; Moreira, M.T.; Feijoo, G.; Lema, J.M. Laccase-catalysed degradation of anti-inflammatories and estrogens. Biochem. Eng. J. 2010, 51, 124-131. [CrossRef]

43. Rodríguez-Rodríguez, C.E.; Marco-Urrea, E.; Caminal, G. Naproxen degradation test to monitor Trametes versicolor activity in solid-state bioremediation processes. J. Hazard. Mater. 2010, 179, 1152-1155. [CrossRef] [PubMed]

44. Tran, N.H.; Urase, T.; Kusakabe, O. Biodegradation characteristics of pharmaceutical substances by whole fungal culture Trametes versicolor and its laccase. J. Water Environ. Technol. 2010, 8, 125-140. [CrossRef]

45. Guzik, U.; Hupert-Kocurek, K.; Wojcieszyńska, D. Intradiol dioxygenases-The key enzymes in xenobiotics degradation in biodegradation of hazardous and special products. InTech 2013, 7, 129-153.

46. Cidaria, D.; Deidda, F.; Bosetti, A. A rapid method for naphtalene dioxygenase assay in whole cells of naphtalene cis-dihydrodiol dehydrogenase blocked Pseudomonas fluoresecens: Screening of potential inducers of dioxygenase activity. Appl. Microbiol. Biotechnol. 1994, 41, 689-693. [CrossRef]

47. Jõesaar, M.; Viggor, S.; Heinaru, E.; Naanuri, E.; Mehike, M.; Leito, I.; Heinaru, A. Strategy of Pseudomonas pseudoalcaligenes C70 for effective degradation of phenol and salicylate. PLoS ONE 2017, 12, e0173180. [CrossRef] [PubMed]

48. Hintner, J.P.; Lechner, C.; Riegert, U.; Kuhm, A.E.; Storm, T.; Reemtsma, T.; Stolz, A. Direct ring fission of salicylate by a salicylate 1, 2-dioxygenase activity from Pseudaminobacter salicylatoxidans. J. Bacteriol. 2001, 183, 6936-6942. [CrossRef] [PubMed]

49. Feng, Y.; Khoo, H.E.; Poh, C.L. Purification and characterization of gentisate 1, 2-dioxygenases from Pseudomonas alcaligenes NCIB 9867 and Pseudomonas putida NCIB 9869. J. Appl. Environ. Microbiol. 1999, 65, 946-950.

50. Tuson, H.H.; Weibel, D.B. Bacteria-surface interactions. Soft Matter 2013, 9, 4368-4380. [CrossRef] [PubMed]

51. Mirpuri, R.; Jones, W.; Bryers, J.D. Toluene degradation kinetics for planktonic and biofilm-grown cells of Pseudomonas putida 54G. Biotechnol. Bioeng. 1997, 53, 535-546. [CrossRef]

52. Priester, J.H.; Horst, A.M.; Van De Werfhorst, L.C.; Saleta, J.L.; Mertes, L.A.; Holden, P.A. Enhanced visualization of microbial biofilms by staining and environmental scanning electron microscopy. J. Microbiol. Methods 2007, 68, 577-587. [CrossRef] [PubMed]

53. Asahi, Y.; Miura, J.; Tsuda, T.; Kuwabata, S.; Tsunashima, K.; Noiri, Y.; Hayashi, M. Simple observation of Streptococcus mutans biofilm by scanning electron microscopy using ionic liquids. AMB Express 2015, 5, 6. [CrossRef] [PubMed]

54. Zhou, D.D.; Dong, S.S.; Gao, L.L.; Liu, M.Y.; Niu, S. Distribution characteristics of extracellular polymeric substances and cells of aerobic granules cultivated in a continuous-flow airlift reactor. J. Chem. Technol. Biotechnol. 2013, 88, 942-947. [CrossRef]

55. Ma, D.; Zou, D.; Zhou, D.; Li, T.; Dong, S.; Xu, Z.; Dong, S. Phenol removal and biofilm response in coupling of visible-light-driven photocatalysis and biodegradation: Effect of hydrothermal treatment temperature. Int. Biodeterior. Biodegrad. 2015, 104, 178-185. [CrossRef]

56. Greń, I.; Wojcieszyńska, D.; Guzik, U.; Perkosz, M.; Hupert-Kocurek, K. Enhanced biotransformation of mononitrophenols by Stenotrophomonas malthophilia KB2 in the presence of aromatic compounds of plant origin. World J. Microbiol. Biotechnol. 2010, 26, 289-295. [CrossRef]

57. Abe, T.; Masai, E.; Miyauchi, K.; Katayama, Y.; Fukuda, M. A tetrahydrofolate-dependent O-demethylase, LigM, is crucial for catabolism of vanillate and syringate in Sphingomonas paucimobilis SYK-6. J. Bacteriol. 2005, 187, 2030-2037. [CrossRef] [PubMed]

58. Wojcieszyńska, D.; Greń, I.; Hupert-Kocurek, K.; Guzik, U. Modulation of FAD-dependent monooxygenase activity from aromatic compounds-degrading Stenotrophomonas maltophilia strain KB2. Acta Biochem. Pol. 2011, 58, 421-426. 
59. Bradford, M.M. A rapid and sensitive method for the quantitation of microgram quantities of protein utilizing the principle of protein-dye binding. Anal. Biochem. 1976, 72, 248-254. [CrossRef] 